\title{
PENERAPAN WEB BASED AUGMENTED REALITY 3D PADA GAME PUZZLE INTERAKTIF KERANGKA MANUSIA
}

Taufich Rizqi Fachrudin*1, Siti Asmiatun ${ }^{2}$

Fakultas Teknologi Informasi dan Komunikasi, Universitas Semaranag Jl. Soekarno Hatta, Tlogsari Kulon, Kec Pedurungan, Kota Semaranag

${ }^{1}$ taufichrizqi@gmail.com, ${ }^{2}$ siti.asmiatun@usm.ac.id

\begin{abstract}
Abstrak- Kemajuan di dalam teknologi komputer memungkinkan kita untuk memberikan tanggapan secara langsung terhadap interaksi pemain dengan aspek-aspek yang ada di dalam game. Dengan dasar pemikiran untuk menggabungkan dunia maya dan dunia nyata, banyak diperoleh ide-ide untuk memudahkan seseorang dalam menciptakan visualisasi yang lebih bagus, efisien, dan imajinatif. Salah satu perkembangan teknologi dan informasi di bidang visualisasi saat ini adalah Augmented Reality. Sebuah sistem Augmented Reality (AR) mengisi dunia nyata dengan benda-benda virtual, sehingga konten yang dihasilkan komputer ditambahkan ke dunia nyata secara interaktif dan real time. Dengan adanya AR, game dapat dirancang menjadi lebih inovatif dan atraktif dengan menampilkan model 3D dari komponen game, salah satu contoh aspek penerapan game yaitu dengan memanfaatkan teknologi augmented reality yang berkembang di era ini kedalam pembuatan games puzzle berbasis web. Dengan memanfaatkan teknologi Augmented Reality, permainan puzzle dapat digunakan sebagai media untuk menambah daya tarik didalam melatih kreatifitas pada anak-anak dengan gameplay yang secara realtime menampilkan visual model 3 Dimensi pada gambar yang seakan-akan berada di dunia nyata.
\end{abstract}

Kata Kunci-Aplikasi, Augmented Reality, Web Based, Game, Puzzle, Multi Marker, Kerangka Tulang Manusia.

Abstract-Advances in computer technology allow us to provide a direct response to the interaction of players with aspects that exist in the game. With the rationale for combining cyberspace and the real world, many ideas are obtained to facilitate someone in creating a better, efficient, and imaginative visualization. One of the developments in technology and information in the current visualization field is Augmented Reality. An Augmented Reality (AR) system fills the real world with virtual objects, so that computer-generated content is added to the real world interactively and in real time. With the existence of $A R$, games can be designed to be more innovative and attractive by displaying $3 D$ models of game components, one example of the aspects of game implementation is by utilizing augmented reality technology that developed in this era into making web-based puzzle games. By utilizing Augmented Reality technology, puzzle games can be used as a medium to add traction in training creativity in children with gameplay that realtime displays $3 D$ visual models in images that seem to be in the real world.

Keywords-Augmented Reality, Application, Web Based, Games, Puzzles, Multi Markers, Human Skeleton.

\section{PENDAHULUAN}

Perkembangan teknologi informasi di era ini sangat pesat ditandai dengan munculnya berbagai teknologi yang baru baik perangkat keras maupun perangkat lunak, khususnya pada bidang visual. Salah satu perkembangan teknologi dan informasi di bidang visualisasi saat ini adalah Augmented Reality. Sebuah sistem Augmented Reality (AR) mengisi dunia nyata dengan benda-benda virtual, sehingga konten yang dihasilkan komputer ditambahkan ke dunia nyata secara interaktif dan realtime. Dengan adanya AR, game dapat dirancang menjadi lebih inovatif dan atraktif dengan menampilkan visual model 3D dari komponen game. Dalam era kemajuan teknologi komputer saat ini, sangat memungkinkan kita untuk memberikan tanggapan secara langsung terhadap interaksi pemain dengan aspek-aspek yang ada di dalam game, salah satu contoh aspek penerapan game yaitu dengan memanfaatkan teknologi augmented reality kedalam pembuatan game.

\section{TINJAUAN PUSTAKA}

Dalam penelitian ini, peneliti menggunakan beberapa sumber pustaka yang digunakan sebagai acuan dan pedoman dalam penelitian yang akan dilakukan. Pustaka yang digunakan ditinjau dari segi objek penelitian, metode yang digunakan, bahasa pemrograman yang digunakan, serta platform yang digunakan dalam penilitian tersebut.

TABEL I

PENELITIAN RELEVAN

\begin{tabular}{|c|c|c|c|c|}
\hline $\begin{array}{c}\text { Tahu } \\
\mathbf{n}\end{array}$ & $\begin{array}{c}\text { Objek } \\
\text { dan } \\
\text { Kasus } \\
\text { ulis }\end{array}$ & $\begin{array}{c}\text { Metod } \\
\text { e AR }\end{array}$ & $\begin{array}{c}\text { Bahasa } \\
\text { Pemro } \\
\text { grama } \\
\text { n }\end{array}$ & $\begin{array}{c}\text { Platfor } \\
\text { m }\end{array}$ \\
\hline & $\begin{array}{c}\text { Animasi } \\
\text { 3D } \\
\text { Kerangka }\end{array}$ & & $\mathrm{C \#}$ & \\
\hline
\end{tabular}


Page | 252

\begin{tabular}{|c|c|c|c|c|}
\hline \begin{tabular}{|l} 
Septri \\
Elvrilla \\
$(2011)$
\end{tabular} & $\begin{array}{c}\text { Manusia } \\
\text { (Edukasi) }\end{array}$ & $\begin{array}{c}\text { Marker } \\
\text { Based } \\
\text { Tracking }\end{array}$ & $\begin{array}{c}\text { Javascrip } \\
\mathrm{t}\end{array}$ & $\begin{array}{c}\text { Androi } \\
\mathrm{d}\end{array}$ \\
\hline $\begin{array}{l}\text { M.Zia } \\
\text { Fadhila } \\
(2013)\end{array}$ & $\begin{array}{l}\text { Anatomi } \\
\text { Tubuh } \\
\text { Manusia } \\
\text { (Edukasi) }\end{array}$ & $\begin{array}{c}\text { Fast } \\
\text { Corner } \\
\text { Detectio } \\
\mathrm{n}\end{array}$ & $\mathrm{C} / \mathrm{C}++$ & $\begin{array}{l}\text { Windo } \\
\text { ws } \\
\text { (Deskt } \\
\text { op) }\end{array}$ \\
\hline $\begin{array}{c}\text { Afif } \\
\text { Nourza } \\
\text { many } \\
(2013)\end{array}$ & $\begin{array}{l}\text { Anatomi } \\
\text { Tubuh } \\
\text { manusia } \\
\text { (Edukasi) }\end{array}$ & $\begin{array}{l}\text { Hough } \\
\text { Transfor } \\
\text { m }\end{array}$ & $\mathrm{C}++$ & $\begin{array}{l}\text { Windo } \\
\text { ws } \\
\text { (Deskt } \\
\text { op) }\end{array}$ \\
\hline $\begin{array}{c}\text { Ririn } \\
\text { Yuliant } \\
\text { i } \\
(2015)\end{array}$ & $\begin{array}{c}\text { Rumah } \\
\text { Adat } \\
\text { Indonesia } \\
\text { (Pengenal } \\
\text { an Rumah } \\
\text { Adat) }\end{array}$ & $\begin{array}{c}\text { Marker } \\
\text { Based } \\
\text { Tracking }\end{array}$ & $\mathrm{C \#}$ & $\begin{array}{c}\text { Androi } \\
\mathrm{d}\end{array}$ \\
\hline $\begin{array}{l}\text { Lucky } \\
\text { Andria } \\
\text { na } \\
\text { Saputr } \\
\text { a } \\
(2016)\end{array}$ & $\begin{array}{c}\text { Animal } \\
\text { (Edukasi } \\
\text { Pengenala } \\
\text { n Hewan) }\end{array}$ & $\begin{array}{l}\text { Multi } \\
\text { Marker }\end{array}$ & $\mathrm{C} \#$ & $\begin{array}{c}\text { Androi } \\
\mathrm{d}\end{array}$ \\
\hline $\begin{array}{c}\text { Konse } \\
\text { p } \\
\text { Aplika } \\
\text { si } \\
\text { Yang } \\
\text { diusulk } \\
\text { an } \\
(2020):\end{array}$ & $\begin{array}{l}\text { Kerangka } \\
\text { Tulang } \\
\text { Manusia } \\
\text { (Game } \\
\text { Puzzle) }\end{array}$ & $\begin{array}{c}\text { Multi } \\
\text { Marker } \\
\text { Based } \\
\text { Tracking }\end{array}$ & $\begin{array}{c}\text { HTML, } \\
\text { Javascrip } \\
\text { t }\end{array}$ & $\begin{array}{l}\text { Berbasi } \\
\text { s Web }\end{array}$ \\
\hline
\end{tabular}

\section{METODOLOGI PENELITIAN}

Metode pengembangan aplikasi yang peneliti gunakan dalam penelitian ini adalah metode Multimedia Development Life Cycle (MDLC) versi Luther-Sutopo dalam Setiawan, Mudiyanto, Lumenta, Ari S.M, dan Tulenan, Virginia [1].

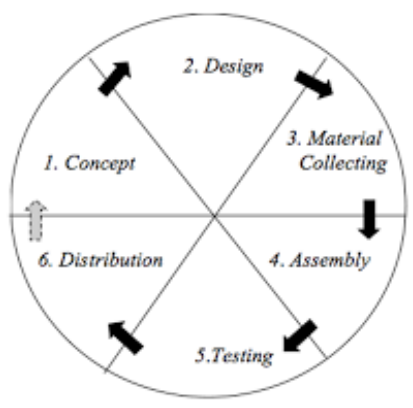

Gbr. 1 Multimedia Development Life Cycle (MDLC) versi Luther-Sutopo (2016:39)

Tahapan pengembangan multimedia menurut Sutopo, dalam Setiawan, Mudiyanto, Lumenta, Ari S.M, dan Tulenan, Virgini [1], adalah sebagai berikut:

\section{Concept (Konsep)}

Tahap concept (konsep) adalah tahapan untuk menentukan tujuan dan siapa pengguna aplikasi (identifikasi audience). Selain itu menentukan macam aplikasi (presentasi, interaktif, dan lain-lain) dan tujuan aplikasi (hiburan, pelatihan, pembelajaran, dll).

2. Design (Perancangan)

Design (perancangan) adalah tahap membuat spesifikasi mengenai arsitektur program, gaya, tampilan dan kebutuhan material atau bahan untuk aplikasi.

3. Material Collecting (Pengumpulan Materi)

Material collecting adalah tahap dimana pengumpulan bahan yang sesuai dengan kebutuhan. Tahap ini dikerjakan secara paralel dengan tahap assembly.

4. Assembly (Pembuatan)

Tahap assembly (pembuatan) adalah tahap dimana semua objek atau bahan multimedia dibuat. Pembuatan aplikasi didasarkan pada tahap design

5. Testing (Pengujian)

Dilakukan setelah selesai tahap pembuatan (assembly) dengan menjalankan aplikasi atau program dan dilihat apakah ada kesalahan atau tidak. Tahap ini disebut juga sebagai tahap pengujian black box testing dimana pengujian dilakukan oleh pembuat atau lingkungan pembuatnya sendiri.

6. Distribution (Distribusi)

Tahapan dimana aplikasi disimpan dalam suatu media penyimpanan. Pada tahap ini jika media penyimpanan tidak cukup untuk menampung aplikasinya, maka dilakukan kompresi terhadap aplikasi tersebut.

Tahapan metode pengembangan aplikasi pada penelitian ini dapat dilihat pada Gbr. 2 : 


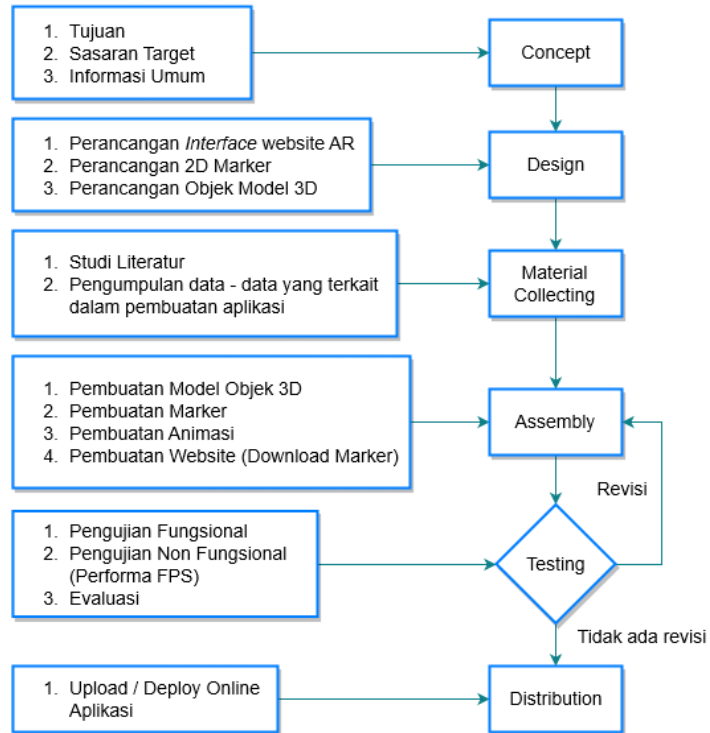

Gbr. 2 Diagram Alir Pengembangan Aplikasi

\section{A. Concept (Konsep)}

Pada tahap ini penulis merumuskan concept dari aplikasi sebagai berkut:

1. Tujuan aplikasi yaitu merancang dan membangun game puzzle augmented reality 3D kerangka manusia berbasis web sebagai sarana alat bantu untuk melatih kreatifitas dan logika kognitif pada anak.

2. Sasaran target pada aplikasi ini adalah anak-anak usia 6 tahun keatas maupun masyarakat umum yang ingin mencoba serta memainkan game dengan teknologi AR.

3. Aplikasi Game Puzzle AR 3D berbasis web dengan model objek Kerangka Manusia dibangun menggunakan software Google SketchUp dengan menerapkan library dari teknologi AR yang berkembang saat ini. Aplikasi ini dapat dioperasikan pada browser yang telah support WebRTC dan WebGL tanpa perlu meng-install.

\section{B. Design (Desain)}

Tahap design dilakukan perancangan untuk interface dari website aplikasi AR, desain vector marker, dan desain model 3D dari objek kerangka manusia. Desain interface adalah tahap pembuatan website aplikasi AR sebagai tempat pendistribusi marker dan sketsa dari tampilan yang akan muncul pada layar smartphone maupun desktop saat pengguna mengoperasikan aplikasi. Tahap ini berkaitan dengan tahap distribution dan dibangun untuk memudahkan interaksi pengguna se-sederhana dan se-efisien mungkin. Rancangan desain website, marker puzzle 2D dan model objek 3D dapat dilihat pada Gbr. 3, Gbr. 4 dan Tabel 3.

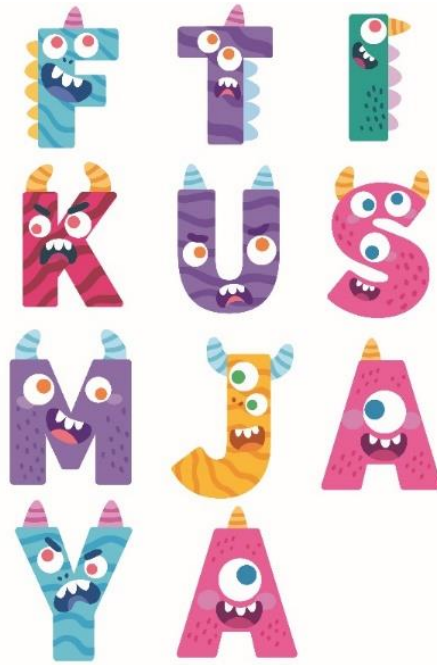

Gbr. 3 Desain Vector Marker

Tampilan pada Gbr. 3 merupakan desain tampilan dari gambar vector marker puzzle font 2D yang untuk pendeteksian dari visual model objek 3D yang terdiri dari :

1. Vector Marker U (Tulang Tengkorak)

2. Vector Marker S (Tulang Iga)

3. Vector Marker M (Tulang Panggul)

4. Vector Marker J (Tulang Kaki Kanan)

5. Vector Marker A (Tulang Telapak Kaki Kanan)

6. Vector Marker Y (Tulang Kaki Kiri)

7. Vector Marker A (Tulang Telapak Kaki Kiri)

8. Vector Marker F (Tulang Lengan Kiri)

9. Vector Marker $\mathrm{T}$ (Tulang Pergelangan Tangan Kiri)

10. Vector Marker I (Tulang Lengan Kanan)

11. Vector Marker K (Tulang Pergelangan Tangan Kanan)

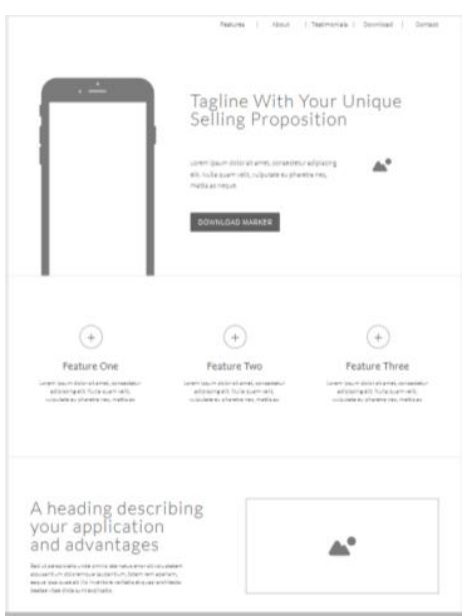

Gbr. 4 Mockup Website AR

Tampilan pada Gbr. 4 merupakan mockup desain tampilan website untuk distribusi aplikasi AR dan sebagai tempat penyimpanan (download) marker. 
TABEL II

DESAIN MODEL OBJEK 3D KERANGKA MANUSIA

\begin{tabular}{|c|c|c|}
\hline No. & Model 3 Dimensi & Keterangan \\
\hline 1. & & $\begin{array}{c}\text { Desain Model 3D } \\
\text { Left Arm (Tulang } \\
\text { Lengan Kiri) }\end{array}$ \\
\hline 2. & & $\begin{array}{c}\text { Desain Model 3D } \\
\text { Left Foot (Tulang } \\
\text { Telapak Kaki } \\
\text { Kiri) }\end{array}$ \\
\hline 3. & & $\begin{array}{c}\text { Desain Model 3D } \\
\text { Left Hand } \\
\text { (Tulang Tangan } \\
\text { Kiri) }\end{array}$ \\
\hline 4. & & $\begin{array}{c}\text { Desain Model 3D } \\
\text { Left Leg (Tulang } \\
\text { Kaki Kiri) }\end{array}$ \\
\hline 5. & & $\begin{array}{c}\text { Desain Model 3D } \\
\text { Pelvis (Tulang } \\
\text { Panggul) }\end{array}$ \\
\hline 6. & & $\begin{array}{l}\text { Desain Model 3D } \\
\text { Ribs (Tulang Iga) }\end{array}$ \\
\hline 7. & & $\begin{array}{c}\text { Desain Model 3D } \\
\text { Right Arm } \\
\text { (Tulang Lengan } \\
\text { Kanan) }\end{array}$ \\
\hline 8. & & $\begin{array}{c}\text { Desain Model 3D } \\
\text { Right Foot } \\
\text { (Tulang Telapak } \\
\text { Kaki Kanan) }\end{array}$ \\
\hline 9. & & $\begin{array}{c}\text { Desain Model 3D } \\
\text { Right Hand } \\
\text { (Tulang Tulang } \\
\text { Kanan) }\end{array}$ \\
\hline 10. & & $\begin{array}{c}\text { Desain Model 3D } \\
\text { Right Leg } \\
\text { (Tulang Kaki } \\
\text { Kiri) }\end{array}$ \\
\hline
\end{tabular}

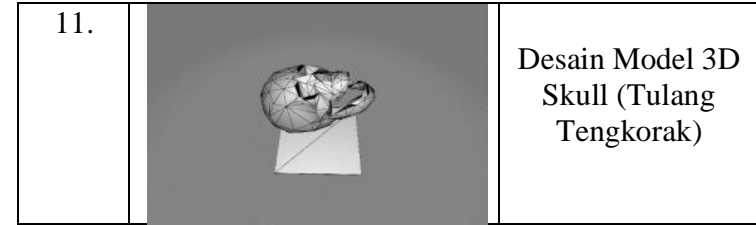

C. Material Collecting (Pengumpulan Materi)

Tahap yang dilakukan pada material collecting merupakan analisa terhadap kebutuhan dalam terapan aplikasi dengan mencari informasi untuk menunjang kesesuaian aplikasi yang akan dibangun. Analisa kebutuhan aplikasi yang akan dilakukan pada penelitian dibagi dengan dua jenis tahapan, yaitu Studi Literatur dan Pengumpulan Data (assets) model 3D.

1. Studi Literatur

Tahap yang dilakukan pada studi literatur merupakan tahap pembelajaran dan pemahaman sesuai dengan masalah yang ada. Dalam kasus ini penulis menggunakan metode penelitian studi literatur dari ebook yang berjudul "Learning Aframe". Ebook ini dibangun oleh para pengembang aplikasi AR agar dapat di operasikan melalui web browser. Berikut gambar ebook yang penulis pakai di dalam studi literatur membangun aplikasi augmented reality berbasis web.

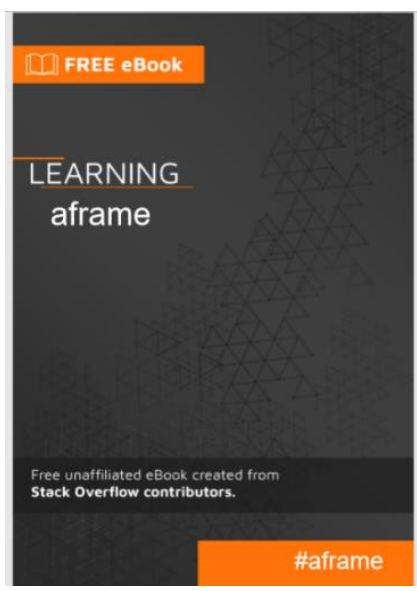

Gbr. 5 E-Book Learning Aframe (RIP Tutorial "Getting Started With Aframe")

2. Pengumpulan Data (Assets)

Tahap pengumpulan data merupakan tahap pengambilan data dari model 3 dimensi. Data (assets) dapat diambil dalam format file .skp .mtl .obj .gltf .dae .fbx .blend dan lain sebagainya. Pada penelitian ini data diambil dalam format file .skp yang merupakan format file yang ada dalam fitur Google SketchUp yaitu 3D Warehouse yang berlisensi open, pengambilan data (assets) bertujuan untuk mempermudah pada saat proses pembuatan bagian-bagian (parts) model 3D dalam game puzzle. Contoh pengambilan assets dalam 3D Warehouse dapat lihat pada Gbr. 5. 


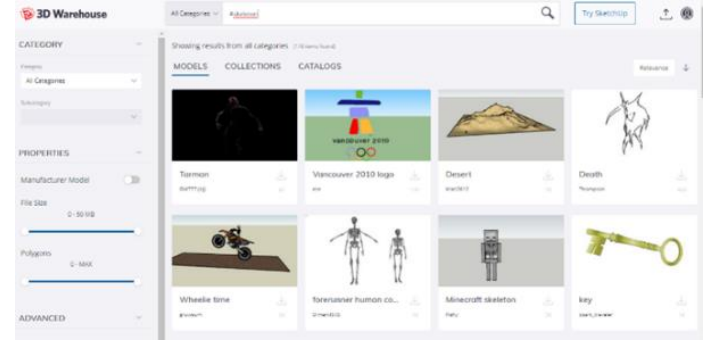

Gbr. 5 3D Warehouse Sketchup

D. Assembly (Pembuatan)

Pada tahap assembly (pembuatan) dilakukan beberapa tahapan, yaitu :

1. Pembuatan Model Objek 3 Dimensi Kerangka Manusia

Pembuatan model 3D yang digunakan peneliti sebagai objek dalam game puzzle AR dibangun dengan menggunakan software SketchUp. Berikut implementasi model objek 3D.

TABEL III

IMPLEMENTASI PART MODEL OBJEK 3D KERANGKA MANUSIA

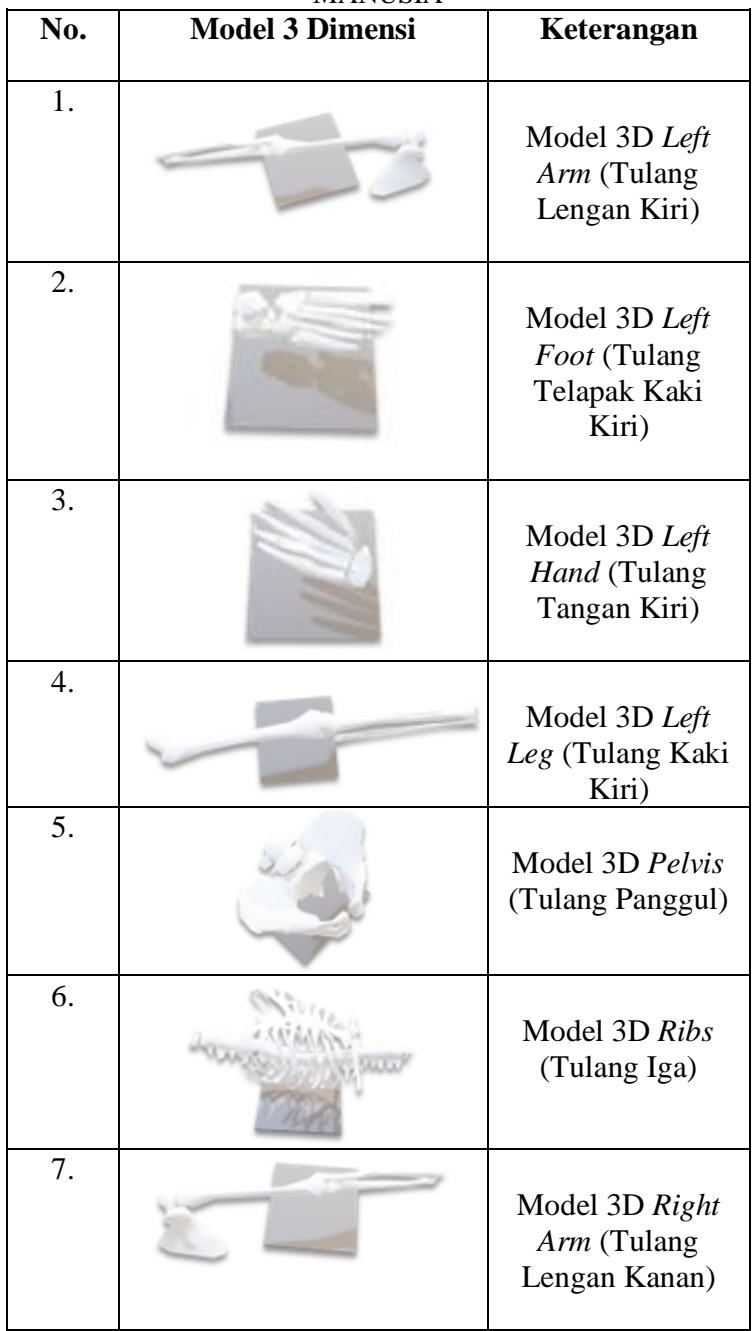

\begin{tabular}{|c|c|c|}
\hline 8. & & $\begin{array}{c}\text { Model 3D Right } \\
\text { Foot (Tulang } \\
\text { Telapak Kaki } \\
\text { Kanan) }\end{array}$ \\
\hline 9. & & $\begin{array}{c}\text { Model 3D Right } \\
\text { Hand (Tulang } \\
\text { Tangan Kanan) }\end{array}$ \\
\hline 10. & & $\begin{array}{c}\text { Model 3D Right } \\
\text { Leg (Tulang Kaki } \\
\text { Kiri) }\end{array}$ \\
\hline 11. & & $\begin{array}{c}\text { Model 3D Skull } \\
\text { (Tulang } \\
\text { Tengkorak) }\end{array}$ \\
\hline
\end{tabular}

2. Pembuatan Marker

Pada tahap pembuatan marker, peneliti menggunakan software photoshop untuk mendesain ulang tampilan marker. Penulis meggunakan marker dengan gambar font yang ketika disusun akan membentuk kalimat "USM JAYA FTIK" sebagai identitas peneliti. Berikut marker yang digunakan sebagai puzzle pada objek 3 dimensi yang peneliti gunakan.

TABEL IV

IMPLEMENTASI MARKER PUZZLE WEBAR

\begin{tabular}{|c|c|c|}
\hline No. & Model 3 Dimensi & Keterangan \\
\hline 1. & $\frac{1}{0}$ & $\begin{array}{c}\text { Marker Puzzle U } \\
\text { (Tulang } \\
\text { Tengkorak) }\end{array}$ \\
\hline 2. & $0^{\circ}$ & $\begin{array}{l}\text { Marker Puzzle S } \\
\text { (Tulang Iga) }\end{array}$ \\
\hline 3. & ${ }_{0}^{\circ} 0^{3}$ & $\begin{array}{l}\text { Marker Puzzle M } \\
\text { (Tulang Panggul) }\end{array}$ \\
\hline 4. & 0 & $\begin{array}{l}\text { Marker Puzzle J } \\
\text { (Tulang Kaki } \\
\text { Kiri) }\end{array}$ \\
\hline 5. & 9 & $\begin{array}{l}\text { Marker Puzzle A } \\
\text { (Tulang Panggul) }\end{array}$ \\
\hline
\end{tabular}




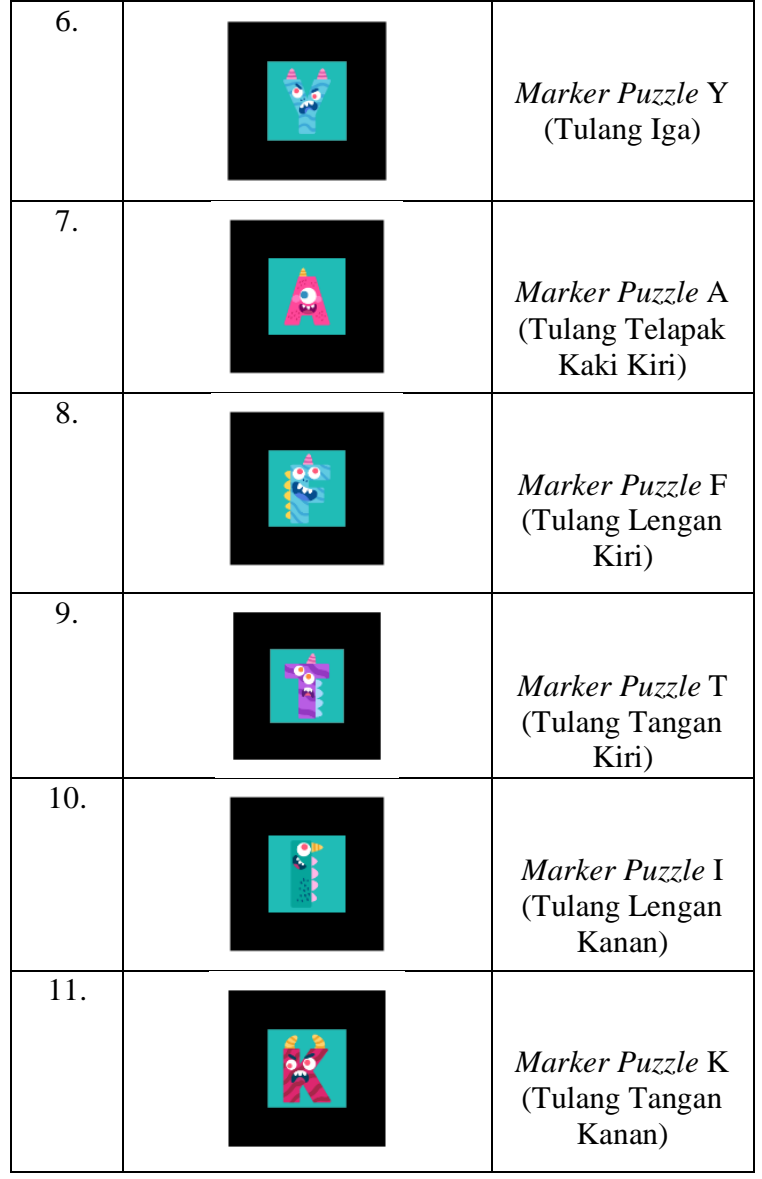

3. Pembuatan Website

Pembuatan website bertujuan untuk tempat pendistribusian (download) marker untuk masyarakat umum (publik) mengingat aplikasi yang peneliti bangun berbasis web, sehingga pengguna (user) dapat mencoba untuk memainkan aplikasi game puzzle AR berbasis web tanpa perlu menginstall. Berikut tampilan halaman website dapat dilihat pada Gbr. 6.

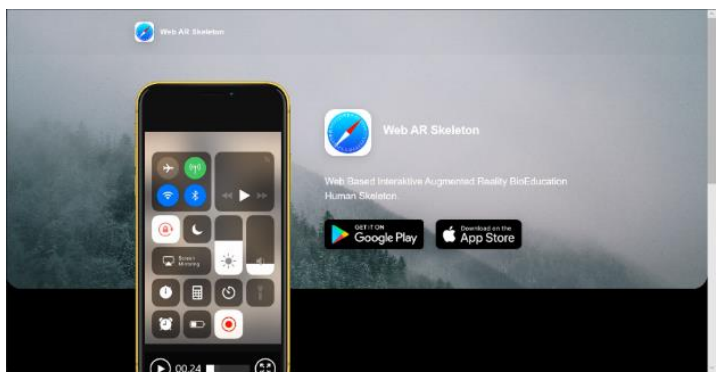

Gbr. 6 Website Game Puzzle AR Kerangaka Manusia

\section{E. Testing (Pengujian)}

Pengujian aplikasi ini menggunakan metode pengujian black box. Pengujian black box memastikan suatu aplikasi dapat menerima masukkan dan melakukan semua kebutuhan fungsional dengan tepat sesuai dengan perancangan. Pada pengujian black box peneliti membagi menjadi beberapa pengujian yaitu:
1. Pengujian Kompabilitas Aplikasi

Pada pengujian kompabilitas aplikasi, peneliti menguji ke dalam beberapa operating system pada device smartphone dengan instrumen sampel pengujian melalui browser seperti Chrome, Mozilla Firefox, dan Safari. Berikut hasil uji kompabilitas yang dilakukan pada aplikasi dapat dilihat pada Tabel V.

TABEL V

UJI KOMPABILITAS APLIKASI

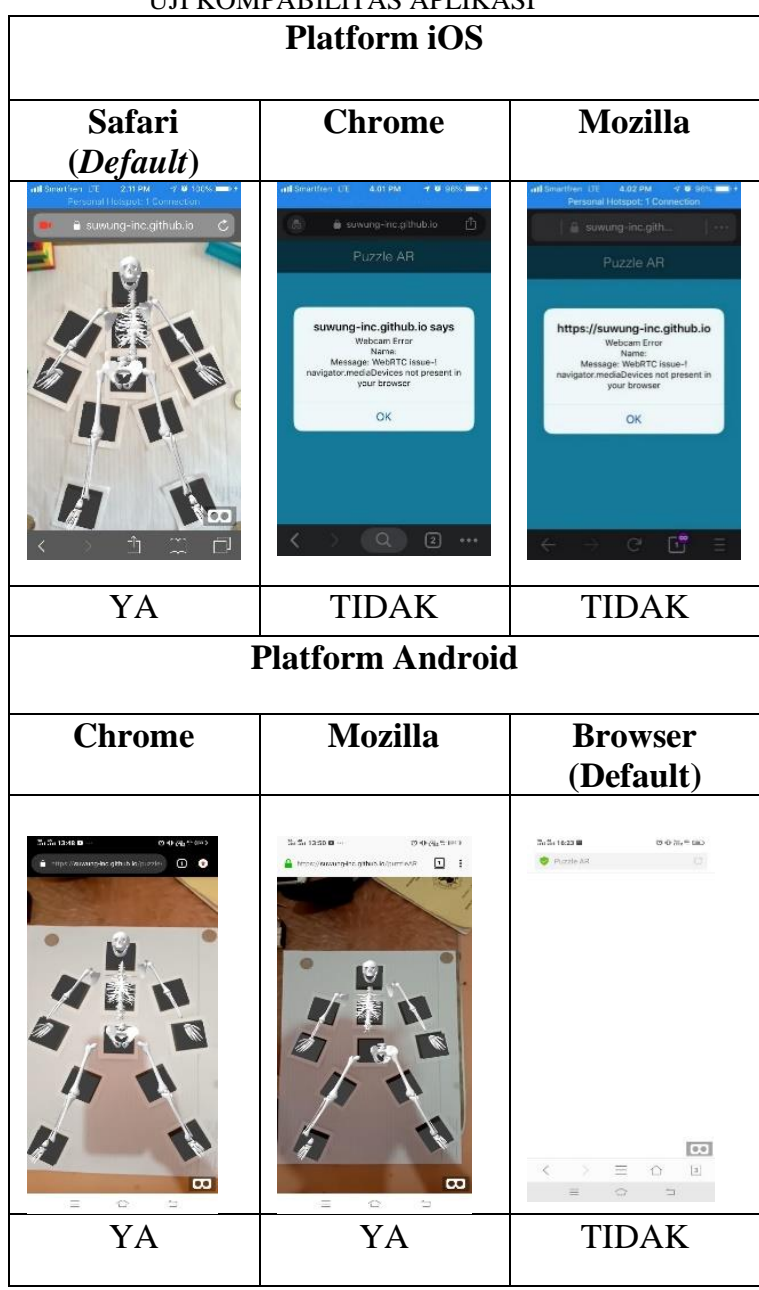

Hasil pengujian pada Tabel. V memperlihatkan bahwa aplikasi Web AR Game Puzzle Kerangka Manusia dapat di operasikan pada Operating System (OS) Android melalui browser Chrome dan Mozilla FireFox, untuk default broswer dari android hanya menampilkan blank white frame. Pada Operating System (OS) iOS aplikasi hanya dapat di operasikan melalui browser Safari, dikarenakan dukungan dari WebRTC pada browser chrome dan mozilla di dalam platform iOS $11+$ menggunakan versi WebRTC yang dibatasi oleh pihak WebKit (web browser engine) dari Apple.Inc. 


\section{Pengujian Kompabilitas Aplikasi}

Pengujian ukuran dan jarak pada marker adalah tahap dimana marker diuji dengan berbagai ukuran beserta jarak yang berbeda-beda, sehingga diketahui hasil yang optimal dari kamera dalam mendeteksi marker. Berikut hasil pengujian dari sampel marker yang digunakan.

TABEL VI

PENGUJIAN JARAK DAN UKURAN SAMPEL MARKER

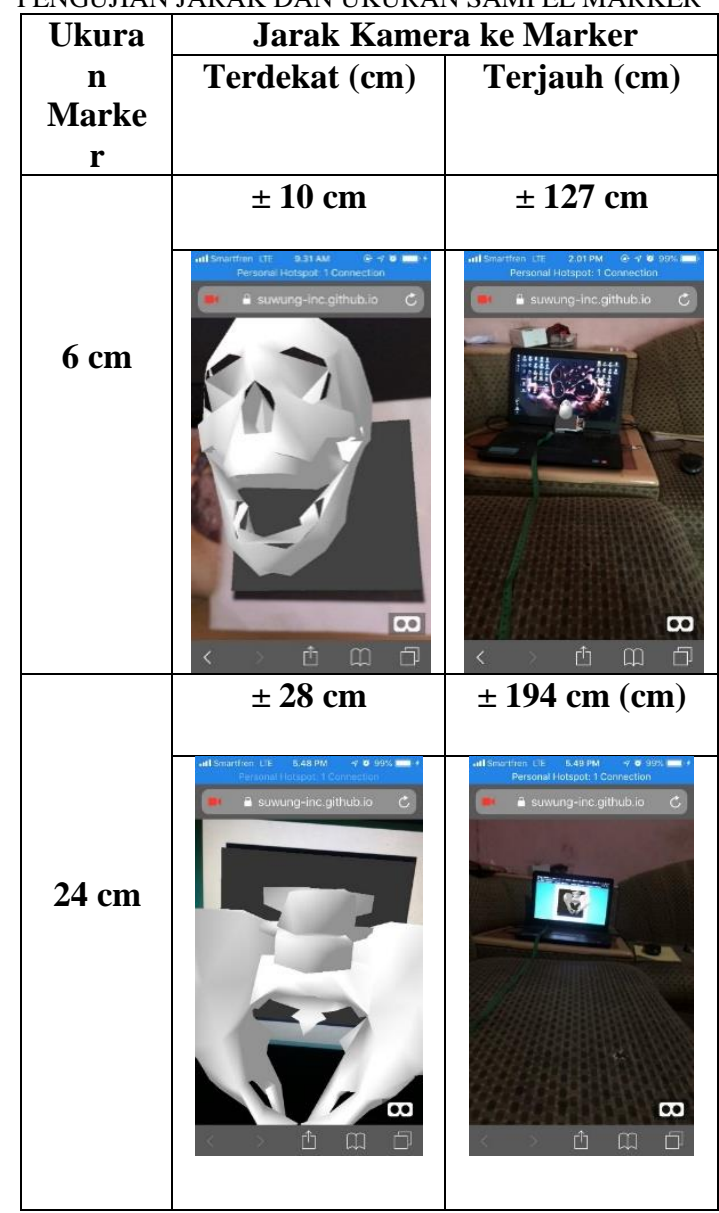

Pada pengujian ukuran dan jarak marker, maka dapat di lihat dengan hasil yang juga berbedabeda dari jarak yang dijangkau oleh kamera untuk mendeteksi sebuah marker. Semakin besar ukuran marker maka jarak jangkauan kamera untuk mendeteksi marker juga akan semakin jauh, sebaliknya semakin kecil ukuran marker maka akan semakin dekat jarak yang dapat dijangkau oleh kamera untuk mendeteksi marker.

3. Pengujian Non Fungsionalitas (FPS)

Pengujian Non Fungsionalitas dilakukan untuk mengukur performa aplikasi secara real time ketika dijalankan pada beberapa device smartphone dengan operating system dan spesifikasi yang berbeda-beda. Berikut pengujian performa dari aplikasi dengan mengambil salah satu sampel dari marker, dapat dilihat pada Tabel VII.
TABEL VII

PENGUJIAN PERFORMA (FPS)

\begin{tabular}{|l|l|}
\hline \multicolumn{1}{|c|}{ Spesifikai } & Performa 38 - 48 FPS \\
OS iOS (iPhone 5S) & \\
Versi 12.4.2 & CPU Dual Core 1.3 \\
GHz Cyclone (ARM \\
v8-based)
\end{tabular}

Hasil pengujian pada Tabel VII, membuktikan bahwa hasil rata-rata FPS dari kedua OS device bisa dikatakan sangat optimal dengan perbandingan normal di dalam aplikasi game yaitu 30 FPS. Sebagai perbandingan, penelitian dari Heri Pratikno (2015) yang berjudul "Kontrol Gerakan Objek 3D Augmented Reality Berbasis Titik Fitur Wajah dengan POSIT, Vol.4, No.1" memiliki performa sekitar 10-15 FPS, penelitian milik Walesa Danto, ST, Agung Toto Wibowo, ST., MT., Bedy Purnama, Ssi., MT (2011) dengan judul "Analisis Metode Occlusion Based Pada Augmented Reality Studi Kasus : Interaksi Dengan Objek Virtual Secara Real Time Menggunakan Gerakan Marker" yang memiliki performa sekitar 20-25 FPS, serta penelitian dari Dimas Setyo Utomo, Issa Arwani, Wibisono Sukmo Wardhono (2017)

\section{F. Distribution (Distribusi)}

Setelah melalui tahap pengujian dan memastikan semua fungsi berjalan dengan semestinya maka aplikasi dianggap layak untuk di distribusikan. Proses distribusi dalam hal ini adalah mengunggah aplikasi webAR Game Puzzle dan website landing page tersebut ke server online. Hasil distribusi Website landing page beserta aplikasi Web AR Game Puzzle dapat di akses pada laman dengan $u r l$ https://trf-web-ar.netlify.com/ 


\section{IV.PENUTUP}

A. Kesimpulan

Berdasarkan dari hasil penelitian yang dilakukan dalam Penerapan Web Based Augmented Reality 3D Pada Game Puzzle Interaktif Kerangka Manusia, maka dapat diambil kesimpulan sebagai berikut:

1. Aplikasi game puzzle augmented reality pada kerangka manusia dapat di operasikan pada perangkat smartphone melalui media dari web browser.

2. Berdasarkan hasil pengujian yang dilakukan pada smartphone dengan OS dan spesifikasi yang berbeda, penerapan aplikasi game puzzle AR berbasis web mempunyai performa FPS yang sangat optimal, dengan hasil pada OS Android yang memiliki performa 46-57 FPS dan OS iOS memiliki performa 38-48 FPS.

3. Dengan memanfaatkan teknologi Augmented Reality, permainan puzzle dapat digunakan sebagai media untuk menambah daya tarik didalam melatih kreatifitas pada anak-anak dengan gameplay yang secara realtime menampilkan visual model 3 Dimensi pada gambar yang seakan-akan berada di dunia nyata.

4. Dengan kegiatan bermain puzzle augmented reality diharapkan dapat melatih konsentrasi dan merangsang daya ingat anak ketika anak bermain puzzle menggunakan gambar marker untuk mendapatkan susunan lengkap dari kerangka tulang manusia yang divisualisasikan secara 3 dimensi

\section{B. Saran}

Saran yang peneliti ingin berikan untuk pengembangan penelitian kedepan terkait dengan Penerapan Web Based Augmented Reality 3D Pada Game Puzzle Interaktif Kerangka Manusia adalah sebagai berikut:

1. Untuk penelitian dan pengembangan selanjutnya diharapkan melakukan inovasi lebih lanjut terhadap model 3D yang diterapkan sebagai objek visual 3D didalam game puzzle augmented reality.

2. Perlunya pengawasan dan bimbingan dari orang dewasa didalam mengoperasikan aplikasi ini, mengingat didalam menjalankan aplikasi menggunakan device smartphone.

3. Didalam pengoperasian aplikasi web AR Game Puzzle pada platform berbasis andorid, disarankan untuk mengubah pengaturan dari default browser kedalam browser chrome atau mozilla firefox

\section{REFERENSI}

[1] RIP Tutorial "Getting Started With Aframe" [Online]. Tersedia : https://riptutorial.com/aframe/topic/10017/gettingstarted-with-aframe. Diakses [05 Oktober 2019].

[2] The Khronos Group Inc [Online]. Tersedia : https://www.khronos.org/blog/. Diakses [02 Desember 2019].

[3] B. Danchilla, "Three.js framework in Beginning WebGL for HTML5". Springer, 2012, pp. 173-203.

[4] XIUQUAN QIAO , PEI REN, SCHAHRAM DUSTDAR , Fellow IEEE, LING LIU, Fellow IEEE, HUADONG MA, AND JUNLIANG CHEN (2019). Web AR: A Promising Future for Mobile Augmented Reality State of the Art, Challenges, and Insights, Vol. 107, No. 4, April 2019.

[5] Siltanen S. Theory and applications of marker-based augmented reality. Technical Research Centre of Finland. ; 39 (2012).

[6] Mahastama, A. W., n.d. Pemanfaatan Computer Vision: Augmented Reality. [Online] Available at: http://www.lecture.ukdw.ac.id[Accessed 23 7:21 AM March 2019].

[7] Patirupanusara P. "Marker-Based Augmented Reality Magic Book for Anatomical Education. In International Conference on Computer and Communication Technologies"; 2012. p. 136-138. 